\title{
MODEL PENGEMBANGAN KELEMBAGAAN PASCA PANEN, PENGOLAHAN HASIL DAN KEMITRAAN USAHA BAWANG MERAH DI SENTRA PRODUKSI MELALUI PELATIHAN DAN PENDAMPINGAN (Studi Kasus Di daerah Sentra Produksi Bawang di Kab. Nganjuk)
}

\author{
Sri Hindarti* \\ *Dosen Program Studi Agribisnis Fakultas Pertanian Universitas Islam Malang \\ Imail: hindartirudy@gmail.com
}

\begin{abstract}
ABSTRAK
Penelitian ini secara umum bertujuan untuk meningkatkan kapasitas kelembagaan kelompok tani melalui pelatihan dan pendampingan penerapan teknologi pengolahan dan pasca panen serta akses pasar bawang merah. Penelitian dilakukan di Kecamatan Sukomoro Kabupaten Nganjuk dengan alasan lokasi tersebut merupakan salah satu daerah sentra produksi bawang merah di Jawa Timur dengan jumlah responden 30 orang petani bawang merah. Penelitian dilakukan selama dua tahun, tahun pertama dilakukan mulai April 2014 sampai dengan Oktober 2015. Penelitian tahun pertama bertujuan untuk mengidentifikasi bentuk penanganan pasca panen pada usahatani bawang merah, menyusun model kelembagaan pasca panen dan menghitung pendapatan usahatani tani bawang merah sebelum dan sesudah menerapkan praktik pasca panen. Penelitian tahun ke dua bertujuan untuk meningkatkan kapasitas kelembagaan penanganan pasca panen dan pengolahan hasil melalui pelatihan pengolahan hasil, mengetahui respon petani terhadap model kelembagaan penanganan pasca panen dan pengolahan hasil. Metode penelitian yang digunakan adalah tahun I pendekatan survey dan tahun II pendekatan kuantitif diskriptif. Data yang digunakan adalah data primer dan data sekunder. Metode analisis data yang digunakan adalah diskriptif kuantatif. Hasil penelitian menunjukkan bahwa hanya $20 \%$ petani bawang merah di Kecamatan Sukomoro Kabupaten Nganjuk menerapkan praktik pasca panen, yakni melakukan pembersihan, pengikatan, pengeringan, grading, pengemasan, penyimpanan, pemberian bahan kimia (kalsium) dan transportasi. Dengan penerapanan praktik pasca panen ini dapat meningkatkan efisiensi usahatani bawang merah dari 1.52 menjadi 2,08, artinya keuntungan usahatani meningkat sebesar $36,84 \%$. Selama ini petani bawang merah belum mengorganisir kegiatan pasca panen dalam kelompok tani tetapi masih berjalan sendiri-sendiri. Oleh karena itu telah disusun Model Kelembagaan Pasca Panen, Pengolahan Hasil dan Kemitraan Usaha Berbasis Pendekatan Kelompok (Gapoktan) agar dapat mengatasi permasalahan tehnis, ekonomi dan sosial petani dalam mengembangkan praktik pasca panen dan pengolahan hasil.
\end{abstract}

Kata Kunci: Pasca Panen dan Pengolahan Hasil, Bawang Merah, Model.

\section{PENDAHULUAN}

\section{Latar Belakang}

Di lihat dari segi ekonomi, usaha bawang merah cukup menguntungkan serta mempunyai pasar yang cukup luas. Konsumsi bawang merah penduduk Indonesia pada saat ini mencapai 650.000 ton, dan konsumsi bawang merah ini meningkat sekitar 5\% setiap tahunnya sejalan dengan bertambahnya jumlah penduduk dan berkembangnya industri olahan. Selain itu peluang ekspor bawang merah segar masih terbuka luas, selain akibat peningkatan konsumsi, peningkatan pemanfaatan bawang merah untuk terapi kesehatan. 
Musim panen (tanam) bawang merah di Indonesia saling melengkapi dengan negara lain, dalam arti, bilamana di negara lain misalnya daratan China sedang musim tanam, maka di Indonesia sedang panen raya, dan sebaliknya. Sehingga kondisi ini memberi peluang masuknya bawang merah impor bawang merahal dari China, Philipina dan India masuk secara ilegal maupun illegal, atau sebaliknya dapat memberi peluang ekspor bawang merah bilamana konsumsi dan kebutuhan industri bawang merah dalam negeri telah dipenuhi (Direktoat Jenderal Pengolahan Dan Pemasaran Hasil Pertanian,2006).

Bawang merupakan salah satu komoditas yang memiliki fluktuasi yang relatif tinggi. Fluktuasi harga bawang dapat disebabkan oleh pasokan impor, harga impor bawang merah dan harga pupuk. Dari ketiga faktor tersebut yang memberikan pengaruh paling besar adalah harga impor bawang merah. Selain itu yang menyebabkan harga bawang merah berfluktuasi adalah masa panen dimana saat panen besar produksi melimpah harga menjadi rendah,sebaliknya saat produksi rendah harga menjadi tinggi. Secara rata-rata nasional, fluktuasi harga bawang cukup tinggi yang diindikasikan oleh koefisien keragaman harga bulanan untuk periode bulan Desember 2010 sampai dengan bulan Desember 2011 sebesar 20,86 \%, yang artinya adalah rentang penyimpangan harga bawang merah bulanan dalam jangka waktu satu tahun terakhir berada dalam kisaran dalam kisaran $+20,86 \%$ dari harga rata-rata nasional dalam periode tersebut. Untuk periode bulan Desember 2010 sampai dengan bulan Desember 2011, harga rata-rata bawang merah nasional yaitu sebesar Rp.19.243/kg, dengan fluktuasi harga yang menurun sejak bulan Juli 2011 hingga Desember 2011. Penurunan harga ini disebabkan karena panen berlangsung bersamaan di beberapa wilayah Jawa tengah, Jawa Timur dan Jawa Barat. Produksi bawang merah lokal meningkat akibat perluasan lahan produksi. Selain itu pasokan bawang meningkat bukan hanya bawang merah dari produksi lokal, tetapi juga bawang impor yang masuk di wilayah Brebes, yang merupakan salah satu sentra penghasil bawang di Indonesia (Fitri Prima Nanda, Ira mega dan Iqlima Idayah, 2011). Strategi pengembangan di lini off-farm diawali dengan perbaikan teknologi pengolahan untuk mendukung pengembangan industri hilir bawang merah (skala rumah tangga maupun industri), misalnya industri irisan kering, irisan basah/utuh, pickles/acar, bawang goreng, bubuk bawang merah, tepung bawang merah, oleoresin, minyak bawang merah, dan pasta. 
Pengembangan industri hilir diarahkan untuk meningkatkan efisiensi pengolahan bawang merah (Litbang Pertanian, 2006).

Namun program ini masih menghadapi banyak kendala di lapangan yakni (1) kegiatan penanganan pascapanen umumnya masih belum dilakukan secara baik oleh petani; (2) industri pengolahan belum banyak berkembang dan masih terbatas pada industri rumah tangga; (3) sistem jaminan mutu belum tersosialisakan dengan baik dan merata; (4) sarana pasca panen, pengolahan dan pemasaran tersedia secara terbatas dan umumnya masih tradisional; (5) tataniaga bawang merah umumnya masih dikuasai oleh tengkulak/pedagang besar; kelembagaan petani bawang merah seperti asosiasi belum berfungsi secara optimal dan lembaga permodalan belum tersedia; (7). skala usaha relatif kecil; (8). distribusi bawang merah belum berjalan dengan baik; (9). pengembangan penanganan pasca panen, pengolahan dan sistem jaminan mutu; (10) pengembangan dan perbaikan sistem distribusi dan pemasaran (Direktoat Jenderal Pengolahan Dan Pemasaran Hasil Pertanian, 2006).

\section{Rumusan Masalah}

Berdasarkan kondisi tersebut, pada penelitian tahun pertama disusunlah permasalahan penelitian sebagai berikut :

1. Bagaimanakan penanganan pasca panen dan tehnologi pengolahan hasil yang dilakukan petani selama ini?

2. Bagaimanakah sarana dan prasarana pasca panen dan pengolahan hasil bawang merah yang dimiliki oleh petani?

3. Bagaimana kelembagaan pasca panen dan pengolahan hasil petani bawang merah selama ini?

4. Bagaimana model kelembagaan pasca panen dan pengolahan hasil yang sesuai?

5. Berapa tingkat efisiensi usahatani bawang merah yang tidak menerapkan dan yang menerapkan praktik penanganan pasca panen?

\section{Tujuan Penelitian}

Berdasarkan latar belakang, penelitian tahun pertama bertujuan untuk : (1) mengetahui praktik penanganan pasca panen bawang merah, (1) mengetahui sarana dan prasarana pasca panen dan pengolahan hasil pada usahatani bawang merah, mengetahui kelembagaan pasca panen dan pengolahan hasil bawang merah, (4) menyusun model kelembagaan pasca panen dan pengolahan hasil usahatani 
bawang merah dan (5) menghitung tingkat efisiensi usahatani bawang merah tidak menerapkan dan menerapkan praktik pasca panen.

Sedangkan penelitian tahun kedua bertujuan untuk : (1) untuk meningkatkan kapasitas kelembagaan pengolahan hasil melalui pelatihan pengolahan hasil, (2) mengetahui respon petani terhadap model kelembagaan penanganan pasca panen dan pengolahan hasil.

\section{Manfaat Penelitian}

1.Sebagai bahan pertimbangan bagi pengambil kebijakan dalam pengembangan agribisnis bawang merah

2.Sebagai bahan informasi bagi penelitian selanjutnya yang berkaitan dengan penelitian ini

$\begin{array}{llr}\text { 3.Bagi peneliti menjadi media } & \begin{array}{l}\text { kelimuan } \\ \text { pengembangan } \\ \text { pengetahuan }\end{array} & \\ \end{array}$

\section{METODE PENELITIAN}

Lokasi Penelitian. Penelitian dilaksanakan Kecamatan Sukomoro Kab. Nganjuk. Pengambilan lokasi tersebut didasarkan atas pertimbangan bahwa lokasi tersebut merupakan salah satu sentra produksi bawang merah terbesar di Jawa Timur (BPS Jawa Timur, 2007).

Penentuan Sampel. Sampel adalah bagian dari populasi yang diharapkan mampu mewakili populasi dalam penelitian, dan populasi atau universe ialah jumlah keseluruhan dari unit analisa yang ciri-cirinya akan diduga. Menurut Teken dalam Masri Singarimbun dan Sofyan Efendi, (1987), dalam penyusunan sampel perlu disusun kerangka sampling yaitu daftar dari semua unsur sampling dalam populasi sampling, dengan syarat: (1) harus meliputi seluruh unsur sampel, (2) tidak ada unsur sampel yang dihitung dua kali, (3) harus up to date, (4) batas-batasnya harus jelas, dan (5) harus dapat dilacak dilapangan.

Adapun tehnik penentuan jumlah sampel dapat menggunakan rumus Taro

Yamane:

$$
n=\frac{N}{N \cdot d^{2}+1}
$$

$\mathrm{n}=$ Jumlah sample,

$\mathrm{N}=$ Jumlah Populasi,

$\mathrm{d}^{2}=$ Presisi yang inginkan (misal $5 \%$ atau $10 \%$ ).

Tehnik Pengambilan Sampel.

Sedangkan tehnik pengambilan sampel dilakukan menggunakan metode Simple random sampling, pengambilan sample secara acak sederhana, ialah sebuah sampel yang diambil sedemikian rupa sehingga tiap unit penelitian atau satuan elemen dari populasi mempunyai kesempatan yang sama untuk dipilih menjadi sample. Metode yang digunakan dengan cara (1) undian 
(digoncang seperti arisan), (2) ordinal (angka kelipatan), (3) tabel bilangan random.

Menurut Suharsimi Arikunto (2002), jumlah sampel yang diambil tergantung pada jumlah populasi, apabila populasi $<100$, maka seluruh anggota populasi digunakan sebagai sampel sedangkan apabila jumlah populasinya > 100 maka dapat diambil sampel antara 10\%-15\%. Setelah kriteria sampel ditentukan yakni petani bawang merah pada Musim Tanam Hujan (bulan Januari-Mei 2014), tidak diperoleh data jumlah populasi petani bawang merah secara pasti, maka ditentukan jumlah sampel sebesar 30 orang. Jumlah ini dianggap telah memenuhi untuk jumlah sampel dalam suatu penelitian.

Pengumpulan Data. Data yang digunakan dalam penelitian ini adalah data primer dan data sekunder. Data primer adalah data yang diperoleh langsung dari petani dengan melakukan wawancara menggunakan kuesioner yang telah disiapkan sebelumnya, sedangkan data sekunder diperoleh dari instansi-instansi yang terkait seperti Kantor Kecamatan, Dinas Pertanian Kabupaten Nganjuk. Metode analisis data yang digunakan untuk tahun pertama adalah metode diskriptif kuantatif.
Analisa Data. Untuk

menjawab tujuan tahun pertama dilakukan dengan analisa data secara kualitatif diskriptif, sedangkan untuk tujuan pada tahun ke dua dilakukan dengan model logit. Sugiyono (2004), analisis deskriptif adalah statistik yang digunakan untuk menganalisa data dengan cara mendeskripsikan atau menggambarkan data yang telah terkumpul sebagaimana adanya tanpa bermaksud membuat kesimpulan yang berlaku untuk umum atau generalisasi. Jadi, analisis deskriptif adalah bagian dari statistik yang digunakan untuk manggambarkan atau mendeskripsikan data tanpa bermaksud mengenaralisir atau membuat kesimpulan tapi hanya menjelaskan kelompok data itu saja.

\section{Analisis Efisiensi Usahatani.}

Analisis efisiensi usahatani digunakan untuk menjawab tujuan 4 yaitu mengetahui efisiensi usahatani bawang merah sebelum dan sudah menerapkan penanganan pasca panen. Untuk mengetahui efisiensi digaunakan rumus:

$$
\mathrm{R} / \mathrm{C} \text { ratio }=\frac{\text { Total Penerimaan }}{\text { Total Biaya }}
$$

$\mathrm{R} / \mathrm{C}<1$, maka usahatani bawang merah tidak efisien

$\mathrm{R} / \mathrm{C}=1$, maka usahatani bawang merah mencapai titik impas

$\mathrm{R} / \mathrm{C}>1$, maka usahatani bawang merah efisien sehingga layak diusahakan 
HASIL DAN PEMBAHASAN

\section{Karakteristik Responden}

\section{Umur Responden}

Umur responden berada pada kisaran kelompok umur 25-77 tahun. Sebaran umur terbanyak adalah pada kelompok umur 36-45 tahun (33\%), golongan umur ini termasuk golongan umur produktif, sehingga kondisi ini akan menjadi suatu potensi yang baik untuk menerima perubahan dan inovasi baru yang disosialisakan. Kelompok umur produktif berikutnya adalah kisaran umur 46-55 tahun (27\%), sedangkan terdapat $23 \%$ terdiri dari kelompok umur lebih dari 55 tahun (23\%), dan sisanya kelompok umur 17\%). Secara rinci umur responden disajikan pada Tabel 1 berikut:

Tabel 1. Umur Responden

\begin{tabular}{|c|l|r|r|}
\hline NO & $\begin{array}{c}\text { UMUR } \\
\text { (tahun) }\end{array}$ & $\begin{array}{c}\text { JUMLAH } \\
\text { (orang) }\end{array}$ & \multicolumn{1}{c|}{$\%$} \\
\hline 1 & $25-35$ & 5 & 17 \\
\hline 2 & $36-45$ & 10 & 33 \\
\hline 3 & $46=55$ & 8 & 27 \\
\hline 4 & $>55$ & 7 & 23 \\
\hline & JUMLAH & 30 & 100,00 \\
\hline
\end{tabular}

Sumber : data primer diolah, 2014

\section{b. Pendidikan Responden}

Sebagian besar responden berpendidikan Sekolah Dasar (SD) (63\%), sedangkan yang berpendidikan Sekolah Menengah Pertama (SMP) sebesar 27\%, , Sekolah Menengah Atas (SMA) sebesar 7\% dan sisanya 3\% berpendidikan Diploma 2. Pendidikan merupakan salah satu faktor yang berpengaruh dalam cara berfikir dan mengambil keputusan penting terkait dengan pengelolaan usahatani bawang merah. Semakin tinggi pendidikan seseorang akan semakin luas dalam cara berfikir dan menganalisis permasalahan dalam kehidupannya, sehingga akan berpengaruh terhadap inovasi baru yang di terimanya.

Tabel 2. Pendidikan Responden

\begin{tabular}{|c|l|r|r|}
\hline NO & PENDIDIKAN & $\begin{array}{c}\text { JUMLAH } \\
\text { (orang) }\end{array}$ & \multicolumn{1}{|c|}{$\%$} \\
\hline 1 & SD & 19 & 63 \\
\hline 2 & SMP & 8 & 27 \\
\hline 3 & SMA & 2 & 7 \\
\hline 4 & D2 & 1 & 3 \\
\hline & JUMLAH & 30 & 100 \\
\hline
\end{tabular}

Sumber : data primer diolah, 2014

\section{c.Luas Lahan}

Luas kepemilikan lahan petani responden adalah berkisar antara 0.11 4,48 hektar dengan rata 0.88 hektar, tetapi sebagian besar (77\%) luas lahan petani responden adalah dibawah 1 hektar, antara 1-2 hektar sebanyak 3\%, 2-3 hektar sebanyak 13\%, 3-4 hektar sebanyak 3\% dan lebih dari 4 hektar sebanyak $3 \%$.

Tabel 3. Luas Kepemilikan Lahan

\begin{tabular}{|c|l|r|r|}
\hline NO & $\begin{array}{c}\text { LUAS } \\
\text { LAHAN }\end{array}$ & $\begin{array}{c}\text { JUMLAH } \\
\text { (Orang) }\end{array}$ & \multicolumn{1}{c|}{$\%$} \\
\hline 1 & $<1 \mathrm{Ha}$ & 23 & 77 \\
\hline 2 & $1<2 \mathrm{Ha}$ & 1 & 3 \\
\hline 3 & $2<3 \mathrm{Ha}$ & 4 & 13 \\
\hline 4 & $3<4 \mathrm{Ha}$ & 1 & 3 \\
\hline 5 & $>4 \mathrm{Ha}$ & 1 & 3 \\
\hline & JUMLAH & 30 & 100 \\
\hline
\end{tabular}

Sumber : data primer diolah, 2014 


\section{d. Jumlah Tanggungan Keluarga}

Tabel 4. Jumlah Tanggungan Keluarga Rata-rata Responden

\begin{tabular}{|c|l|r|r|}
\hline NO & $\begin{array}{l}\text { JUMLAH } \\
\text { TANGGUNGAN } \\
\text { KELUARGA }\end{array}$ & $\begin{array}{c}\text { JUMLAH } \\
\text { (Orang) }\end{array}$ & \multicolumn{1}{c|}{$\%$} \\
\hline 1 & $2-3$ ORANG & 5 & 16,7 \\
\hline 2 & $4-5$ ORANG & 20 & 66,7 \\
\hline 3 & $6-7$ ORANG & 2 & 6,7 \\
\hline 4 & 8-9 ORANG & 3 & 10 \\
\hline & JUMLAH & 30 & 100 \\
\hline
\end{tabular}

Sumber : data primer diolah, 2014

\section{Kegiatan Pasca Panen Dan}

\section{Pengolahan Hasil Petani Bawang}

Merah

Kegiatan pasca panen atau pasca produksi (Postproduction) diartikan sebagai berbagai tindakan atau perlakuan yang diberikan pada hasil pertanian setelah panen sampai komoditas berada di tangan konsumen. Kegiatan pasca produksi dibagi menjadi dua tahap yakni pasca panen (postharvest) dan pengolahan (processing). Penanganan pasca panen (postharvest) sering disebut juga sebagai pengolahan primer (primary processing), yakni merupakan istilah yang digunakan untuk semua perlakuan dari mulai panen sampai komoditas dapat dikonsumsi "segar" atau untuk persiapan pengolahan berikutnya. Umumnya perlakuan tersebut tidak mengubah bentuk penampilan atau penampakan, kedalamnya termasuk berbagai aspek dari pemasaran dan distribusi. Pengolahan (secondary processing) merupakan tindakan yang mengubah hasil tanaman ke kondisi lain atau bentuk lain dengan tujuan dapat tahan lebih lama (pengawetan), mencegah perubahan yang tidak dikehendaki atau untuk penggunaan lain. Ke dalamnya termasuk pengolahan pangan dan pengolahan industri.

Tujuan penanganan pasca panen secara umum adalah agar hasil tanaman tersebut dalam kondisi baik dan sesuai/tepat untuk dapat segera dikonsumsi atau untuk bahan baku pengolahan. Prosedur/perlakuan dari penanganan pasca panen berbeda untuk berbagai tanaman. Sedangkan tujuan utama untuk menerapkan teknologi pascapanen pada tanaman bawang merah adalah mempertahankan kondisi segarnya dan mencegah perubahanperubahan yang tidak dikehendaki selama penyimpanan, seperti busuk, pertumbuhan akar, buah keriput, dll. Dengan demikian maka mutu lebih terjaga dan mengurangi susut sehingga harga jual lebih tinggi.

Bentuk penanganan pasca panen pada bawang merah di Kecamatan Sukomoro Kabupaten Nganjuk dibedakan menjadi dua yakni penanganan segera setelah panen dan pasca panen. Penanganan segera setelah panen terdiri dari pengeringan, pengikatan dan pembersihan; sedangkan pasca panen terdiri dari grading, pengemasan, penyimpanan, 
pengangkutan dan pemberian bahan kimia. Dari hasil penelitian di lapang diperoleh data bahwa hanya 20\% (6 responden) yang melakukan penanganan pasca panen, sedang sebanyak 80\% (24 responden) tidak melakukan karena hasil panen langsung dijual segera setelah panen. Hasil selengkapnya penanganan pasca panen bawang merah di Kecamatan Sukomoro disajikan pada Tabel 5 dibawah ini.

Tabel 5. Perlakuan Pasca Panen Pada Usahatani Bawang Merah Di Kecamatan Sukomoro Kabupaten Nganjuk Tahun 2014

\begin{tabular}{|c|l|c|c|c|cc|c|}
\hline NO & MELAKUKAN & $\begin{array}{c}\text { JUMLAH } \\
(\text { Orang) }\end{array}$ & $\%$ & MELAKUKAN & $\begin{array}{c}\text { TUMLAH } \\
(\text { Orang })\end{array}$ & TOTAL \\
\hline 1 & Pengeringan & 6 & 20 & Pengeringan & 24 & 80 & $30(100 \%)$ \\
\hline 2 & Pengikatan & 6 & 20 & Pengikatan & 24 & 80 & $30(100 \%)$ \\
\hline 3 & Pembersihan & 6 & 20 & Pembersihan & 24 & 80 & $30(100 \%)$ \\
\hline 4 & Grading & 6 & 20 & Grading & 24 & 80 & $30(100 \%)$ \\
\hline 5 & Pengemasan & 6 & 20 & Pengemasan & 24 & 80 & $30(100 \%)$ \\
\hline 6 & Penyimpanan & 6 & 20 & Penyimpanan & 24 & 80 & $30(100 \%)$ \\
\hline 7 & Pengangkutan & 6 & 20 & Pengangkutan & 24 & 80 & $30(100 \%)$ \\
\hline 8 & Bahan Kimia & 6 & 20 & Bahan Kimia & 24 & 80 & $30(100 \%)$ \\
\hline
\end{tabular}

Sumber : data primer diolah, 2014

\section{1). Penanganan Segera Setelah Panen}

Sebelum dilakukan penanganan pasca panen seringkali dilakukan kegiatan penanganan segera setelah panen, dimana tindakan tersebut berbeda-beda pada setiap hasil tanaman. Tindakan tersebut bila tidak dilakukan segera, akan menurunkan kualitas dan mempercepat kerusakan sehingga komoditas tidak tahan lama disimpan. Pada tanaman bawang merah perlakuan tersebut dilakukan oleh petani yang ingin menjual hasil tanaman bawang merah sebagai bibit yakni hanya 20\% dari responden, sedangkan yang menjual bawang merah konumsi tidak melakukan. Perlakuan tersebut antara lain adalah : a. Pengeringan (drying) bertujuan mengurangi kadar air dari komoditas. Pada bawang merah pengeringan hanya dilakukan sampai kulit mengering. Petani di Kecamatan Sukomoro melakukan kegiatan ini khususnya untuk tanaman bawang merah yang dijual dalam bentuk bibit, sedangkan yang untuk konsumsi lebih banyak yang dijual langsung tanpa melalui pengeringan terlebih dahulu.

b. Pengikatan (bunching) dilakukan pada bawang merah dengan tujuan untuk memudahkan penanganan dalam penyimpanan dan pemindahan serta mengurangi kerusakan. 
c. Pembersihan ( cleaning, trimming) yaitu membersihkan dari kotoran atau mengambil bagian-bagian yang tidak dikehendaki seperti daun, tangkai atau akar yang tidak dikehendaki.

\section{2).Penanganan Pasca Panen}

Secara umum pasca panen meliputi pekerjaan yaitu Grading (pengkelasan) dan standarisasi, pengemasan dan pelabelan, penyimpanan dan pengangkutan serta pada beberapa komoditas ada yang diberi perlakuan tambahan antara lain : pemberian bahan kimia.

\section{a. Grading dan Standarisasi}

Grading adalah pemilahan berdasarkan kelas kualitas. Biasanya dibagi dalam kelas 1, kelas 2, kelas 3 dan seterusnya, atau kelas A, kelas B, kelas $\mathrm{C}$ dan seterusnya. Pada beberapa komoditas ada kelas super-nya. Tujuan dari tindakan grading ini adalah untuk memberikan nilai lebih ( harga yang lebih tinggi) untuk kualitas yang lebih baik. Standard yang digunakan untuk pemilahan (kriteria ) dari masing-masing kualitas tergantung dari permintaan pasar. Dari hasil wawancara dengan petani responden diketahui bahwa para petani bawang merah di Kecamatan Sukomoro hanya $20 \%$ yang melakukan dan sebagian besar (80\%) tidak melakukan kegiatan grading karena mereka menjual langsung hasil panennya kepada para tengkulak yang setiap hari berkeliling mencari tanaman bawang merah yang siap panen, selanjutnya para tengkulak yang melakukan fungsi grading dan standarisasi. Model penjualan dengan menggunakan sistem borongan berdasarkan taksiran yang dibuat oleh para tengkulak. Hal ini mereka lakukan dengan beberapa alasan diantaranya tidak mau repot, kebutuhan uang yang mendesak, belum menguasai tehnologi pasca panen dan pengolahan hasil bawang merah, tidak memiliki sarana dan prasarana perlakuan pasca panen dan pengolahan hasil.

\section{b. Pengemasan / pengepakan / pembungkusan}

Penanganan pasca panen berikutnya adalah pengemasan. Keuntungan dari pengemasan yang baik adalah (1) melindungi komoditas dari kerusakan mekanis (gesekan, tekanan, getaran), dari pengaruh lingkungan (temperatur, kelembaban, angin), dari kotoran / pencemaran (sanitasi) dan dari kehilangan (pencurian), memudahkan pengontrolan dan penanganan, (4) penggunaan berbagai fasilitas pengemasan memudahkan penanganan, (5) memberikan kesinambungan dalam penanganan, (6) meningkatkan pelayanan dalam pemasaran yaitu praktis untuk konsumen (pengemasan dalam skala 
kecil), lebih menarik, dapat untuk menyampaikan informasi produk yang dikemas, penggunaan label dapat menerangkan cara penggunaan dan cara melindungi produk yang dikemas, mengurangi / menekan biaya transportasi / biaya tataniaga.

Pada tanaman bawang merah di Kecamatan Sukomoro kegiatan pengemasan sebagian besar responden (80\%) tidak dilakukan oleh petani karena hasil panen dijual langsung di sawah setelah panen. Kegiatan ini hanya dilakukan oleh $20 \%$ responden terutama responden yang berusahatani bawang merah untuk dijual sebagai bibit pada musim tanam yang akan datang, dengan membungkus bawang merah dengan jaring plastik dengan berat 25 50/kilogram. Sedangkan responden yang tidak melakukan, maka penanganan pasca panen ini dilakukan oleh para tengkulak bawang merah.

\section{3). Penyimpanan (Storage operation)}

Tujuan melakukan kegiatan penyimpanan adalah memperpanjang kegunaan (dalam beberapa kasus, meningkatkan kualitas), menampung produk yang melimpah, menyediakan komoditas tertentu sepanjang tahun, membantu dalam pengaturan pemasaran, meningkatkan keuntungan finansial bagi produsen dan mempertahankan kualiatas dari komoditas yang disimpan. Dari hasil wawancara dengan responden di
Kecamatan Sukomoro diketahui bahwa kegiatan penyimpanan hasil hanya dilakukan oleh petani bawang merah yang ditujukan untuk bibit yakni $20 \%$ dari responden, sedangkan petani yang mmenjual hasil panen untuk konsumsi tidak melakukan kegiatan penyimpanan hasil tetapi kegiatan ini dilakukan oleh para tengkulak. Penyimpanan dilakukan dengan menggantung bawang merah di plafon teras rumah atau di letakkan pada widig bambu yang terhampar di halaman rumah dan ditutupi dengan penutup bambu/plastik untuk melindungi dari hujan. Dalam penelitian karena penyimpanan dilakukan di rumah sendiri sehingga biaya penyimpanan tidak diperhitungkan.

\section{4). Pengangkutan}

Pengangkutan umumnya diartikan sebagai penyimpanan berjalan. Semua kondisi

penyimpanan pada komoditas yang diangkut harus diterapkan. Faktor pengangkutan yang perlu diperhatikan adalah fasilitas angkutannya, jarak yang ditempuh atau lama perjalanan

, kondisi jalan dan kondisi lingkungan selama pengangkutan, perlakuan "bongkar-muat" yang diterapkan. Kegiatan pengangkutan hanya dilakukan oleh $20 \%$ responden sedang sisanya tidak melakukan tetapi dilakukan oleh para tengkulak. Hal ini disebabkan responden menjual langsung hasil panen 
di sawah kepada tengkulak yang mendatanginya.

\section{5). Pemberian bahan kimia:}

Berbagai tujuan pemberian bahan kimia, antara lain Insektisida atau fungisida untuk mencegah serangan hama dan penyakit setelah panen, pemberian kapur untuk menghambat pertunasan,

Hasil wawancara kepada para petani bawang merah untuk konsumsi diperoleh hasil bahwa sebagian besar petani menjual langsung hasil panen tanaman bawang merah kepada para pedagang yang setiap hari mendatangi kerumah-rumah atau sawah petani sehingga tidak melakukan penanganan pemberian bahan kimia. Pemberian bahan kimia yakni Calsium dilakukan oleh petani sebanyak 20\% dari responden yang menjual untuk bibit. Tujuan adalah untuk mengawetkan sehingga bawang merah tetap segar dan siap ditanam. Seperti diketahui bahwa bibit bawang merah di Sukomoro Kabupaten Nganjuk dikenal memiliki kualitas yang baik dan di gunakan oleh petani bawang merah di daerah lain di Indonesia. Dengan alasan inilah para petani melakukan penanganan pasca panen untuk menyimpan hasil yang akan dijual sebagai bibit di musim yang akan datang. Model ini lebih disukai petani karena harga jual bibit bawang merah lebih tinggi dibandingkan harga jual bawang merah untuk konsumi, yakni Rp $12.000,-/ \mathrm{kg}$ untuk konsumsi dan $\mathrm{Rp}$ 15.000-Rp. 25.000,-/kg untuk bibit.

\section{Sarana dan Prasarana Pasca Panen} Dan Pengolahan Hasil

Dari hasil pengamatan dilapang diketahui bahwa sebagian besar $(80 \%)$ responden tidak memiliki sarana dan prasarana pasca panen dan pengolahan hasil, sedangkan $20 \%$ responden memiliki sarana dan prasarana yang relatif masih sederhana seperti tempat penyimpanan hasil. Model penyimpanan hasil secara umum dilakukan dengan membuat meja panjang dari anyaman bambu (disebut widig) di halaman sekitar rumah atau di plafon teras depan/ belakang rumah untuk meletakkan bawang merah yang telah diikat dan ditaburi oleh Calsium terlebih dahulu. Selanjutnya ditutup dengan tutup sesek untuk menghalangi dari air hujan. Dengan cara ini bawang merah dapat dismpan samapi 68 bulan sampai periode tanam berikutnya. Model penyimpanan ini sangat rentan apabila terjadi hujan.

Bawang merah merupakan salah satu hasil pertanian jenis hortikultura yang dibutuhkan oleh masyarakat Indonesia sebagai bumbu aneka masakan, yang dapat diolah menjadi bermacam bentuk hasil olahan seperti bawang goreng, pasta bawang merah, krupuk bawang dll. Diantara berbagai 
bentuk pengolahan tersebut belum ada responden yang melakukan dikarenakan belum memiliki pengetahuan (tehnolgi) dan fasilitas pengolahan yang dibutuhkan.

\section{Kemitraan}

Pemasaran termasuk salah satu faktor yang seringkali menjadi kendala dalam melakukan kegiatan usaha, termasuk dalam agribisnis bawang merah. Oleh karena perlu dilakukan upaya untuk membantu meningkatkan akses pasar hasil produksi bawang merah petani. Salah satu upaya yang sering dianggap ampuh mengatasi kendala pemasaran adalah dengan membangun kemitraan pemasaran. Dengan kemitraan pesamaran diharapkan pasar hasil dan harga jual produk terjamin, sehingga diharapkan pendapatan meningkat. Kemitraan dapat dibangun melalui Kelompok Tani disetiap wilayah yang tergabung dalam Gapoktan. Selanjutnya Gapoktan melakukan kemitraaan dengan industri dan pasar. Untuk bawang merah di Kecamatan Sukomoro belum dilakukan kemitraan, baik dengan industri maupun pasar lokal, regional maupun nasional. Bentuk hubungan dagang yang terjalin hanya bersifat sesaat yakni saat ada permintaan dan barang tersedia. Oleh karena itu dalam rangka pengembangan di masa yang akan datang perlu untuk dirancang model kemitraaan usaha bawang merah.

\section{Kelembagaan Pasca Panen Sebelum} Penelitian

Tiga kunci kelembagaan adalah : nilai dan norma, pola perilaku yang dibakukan (disebut prosedur umum) dan sistem hubungan yakni peran dan status yang menjadi wahana melaksanakan perilakusesuai prosedur umum. Lembaga adalah adalah suatu himpunan atau tatanan norma-norma dari segala tingkatan yang berkisar pada kebutuhan pokok di dalam kehidupan masyarakat (Soerjono Soekanto, 2002).

Nilai dan norma pasca panen yang berlaku dalam usahatani bawang merah selama ini sebagian besar (80\%) masih berorientasi pada pada produksi belum berorientasi kepada pasar, sehingga responden belum termotivasi untuk melakukan kegiatan praktik penanganan pasca panen apalagi pengolahan. Dengan tersebut dan pertimbangan kebutuhan uang tunai yang mendesak, responden menjual langsung hasil panennya kepada tengkulak tanpa melakukan penanganan pasca panen. Dengan kondisi tersebut terbangun hubungan pemasaran antara responden sebagai produsen dengan tengkulak sebagai pembeli yang memberikan kemudahan dalam pemasaran dengan jalan tengkulak mendatangi responden di sawahnya. 
Petani bawang merah selama ini melakukan kegiatan pasca panen sendiri

Model Pengembangan Kelembagaan

Pasca Panen dan Pengolahan Hasil dan Kemitraan Usaha

Permasalahan

Pengembangan

Penanganan Pasca Panen dan

Pengolahan Hasil Bawang Merah

Hasil identifkasi dan analisis lapangan diketahui beberapa permasalahan pengembangan pasca panen, pengolahan hasil yang dikelompokkan menjadi tiga, yakni :

1) Masalah Teknis : tingkat pengetahuan dan kesadaran petani di bidang teknis dan manajemen penanganan pasca panen masih terbatas, introduksi sarana dan teknologi pasca panen belum ada, kurangnya tenaga yang terampil dalam peralatan pasca panen.

2) Masalah Ekonomi : daya beli alat dan mesin pasca panen rendah, harga alat mesin pasca panen relatif masih mahal, belum tersedianya skim kredit khusus untuk pengadaan/usaha alsin pasca panen, kemampuan permodalan masih rendah, kurangnya informasi pasar sehingga akses pasar dan pemasaran terbatas.

3). Masalah Sosial : kebutuhan petani akan uang tunai untuk keperluan keluraga yang mendesak . tanpa ada organisasi formal yang menaungi.

\section{Strategi Pengembangan Kelembagaan}

Pasca Panen dan Pengolahan Hasil

\begin{tabular}{llr}
\multicolumn{1}{c}{ Untuk } & $\begin{array}{r}\text { melaksakan } \\
\text { penanganan }\end{array}$ \\
pengembangan & & $\begin{array}{c}\text { permasalahan pasca } \\
\text { panen dan }\end{array}$
\end{tabular} pengolahan hasil dapat ditempuh melalui tiga cara yakni:

1. Strategi Pendekatan Wilayah melaui Penumbuhan dan Pengembangan Kelembagaan (Kecamatan) Pasca Panen berbasis Kelopmpok (Gapoktan) dan Kemitraan Usaha antara Gapoktan dengan Industri dan Pasar.

2. Strategi Pendekatan Sarana Prasarana melalui Pengembangan, Penyebaran dan Optimalisasi Pemanfaatan Sarana dan Teknologi Pasca Panen.

3. Strategi Pendekatan Sumberdaya Manusia (SDM) melaui Pembinaan, Penyuluhan, Bimbingan Teknis, Pelatihan, Pendampingan, Supervisor dan Pengawalan.

\section{Langkah Operasional Pengembangan}

1) Penyelamatan/ memperpanjang daya simpan produk dan penurunan kehilangan/susut hasil, dengan kegiatan :

a) menumbuh kembangkan kelembagaan pasca panen berbasis gapoktan 
b) meningkatkan kemampuan dan ketrampilan petani dibidang teknis dan manajemen penanganan pasca panen

c) pengadaan dan penyaluran alat mesin pasca panen tepat guna melalui dana APBN/APBD maupun Swasta, d) pengembangan unit pelayanan jasa alat mesin pasca panen.

2) Peningkatan kualitas/mutu hasil, dengan kegiatan : a) Grading dan Packaging House serta pergudangan berbasis jaminan mutu produk, b) Bimbingan teknis dan manajemen penerapan SOP dan GHP penanganan pasca panen.

3) Fasilitasi pemanfaatan modal baik melalui skim kridit perbankan (KUMP/KKP/KUR) dan BLM atau Dana Bantuan Sosial.

4). Pelatihan, Bimbingan Teknis, Pendampingan, supervisor dan pengawalan

5). Menjalin Kerjasama Kemitraan Usaha antara Gapoktan dengan perusahaan agroindustri di daerah.

6). Monitoring, Evaluasi dan Pelaporan

\section{Model Kelembagaan Pasca Panen,}

\section{Pengolahan Hasil dan Kemitraan}

\section{Usahatani Bawang Merah}

Permaslahan pasca panen, pengolahan hasil dan pemasaran sering diabaikan dan tidak menjadi perhatian utama.
Berdasarkan hasil identifikasi dan analisis masalah yang dilakukan dalam kegiatan usahatani bawang merah di Kecamatan Sukomoro khususnya tentang perlakuan pasca panen dan pengolahan hasil bawang merah maka disusunlah model pengembangan kelembagaan pasca panen dan pengolahan hasil.

Penanganan pasca panen dapat dibedakan menjadi dua tahapan yakni tahap penanganan segera setelah panen dan tahap pasca panen. Perlakuan yang diberikan segera setelah panen meliputi pengikatan, sortasi dan pengeringan. Perlakuan pasca panen meliputi pembersihan, grading, pengepakan/pengemasan dan labeling, pengangkutan dan pemasaran. Pemasaran dapat dilakukan melalui dua cara yakni menjual kepada konsumen akhir di pasar dan menjalin kemitraan pemasaran dengan industri pengolah bawang goreng atau warung/restauran /pengusaha catering, eksportir. Keuntungan penanganan pasca tersebut adalah dapat menjaga kualitas bawang merah, memudahkan pemasaran dan harga jual lebih tinggi sehingga akan dapat meningkatkan keuntungan. Selama ini petani hanya bertindak sebagai produsen sehingg dalam mengelola usahataninya. Kondisi demikian menyebabkan rendahnya 
keuntungan yang diterima petani dari kegiatan produksi yang dilakukannya.

$$
\text { Pendekatan baru dalam }
$$

pengembangan usahatani menekankan pentingnya petani untuk tidak hanya bertindak sebagai produsen namun juga menjadi pemasok atau "supplier". Petani harus dilibatkan sebagai pemasok pasar dalam pengembangan Farm-Gate Marketing System. Pendekatan dalam menyelesaikan permasalahan pasca panen dan pengolahan serta pemasaran hasil dapat dilakukan melalui pendekatan kelompok, dimana GAPOKTAN harus menjadi basis dan landasan peningkatan daya saing, nilai tambah, posisi tawar, dan peningkatan pendapatan. Dalam Farm-Gate Marketing System kegiatan usahatani bawang merah akan dikembangkan sehingga :

1. Terjadi integrasi yang kuat dalam jaringan pemasaran lokal, wilayah dan nasional dan orientasi pasar bersifat domestik, subsitusi impor, maupun pengembangan ekspor.

2. Berbasis pada Keuntungan Komparatif (Comparative Advantage) wilayah untuk komoditas unggulan (one village one commodity).
- Berazaskan keterpaduan :

Keterpaduan Hulu - Hilir, Keterpaduan wilayah sehingga memenuhi skala ekonomi usaha (economy of scale) dan Hubungan Gapoktan dan Industri akan terjalin dalam suatu kemitraan usaha/ sistem agribisnis terpadu

Analisis Efisiensi Usahatani Bawang Merah Yang Tidak Menerapkan

\section{a. Biaya Tetap Usahatani Bawang}

\section{Merah}

Biaya tetap dalam usahatani bawang merah terdiri dari sewa lahan dan biaya penyusutan alat seperti cangkul, sprayer, parang dan timba. Tabel 6. menyajikan besarnya biaya tetap pada usahatani bawang merah. Rata-rata biaya tetap per Hektar adalah Rp. 682.500,00, sedangkan rata-rata sewa lahan Rp. 500.000,-, rata-rata pemakaian cangkul selama 24 bulan sebesar Rp 66.667,-, rata-rata pemakaian sprayer selama 60 bulan sebesar Rp. 53.333,- rata-rata pemakaian parang selama 24 bulan sebesar Rp. 20.833,dan pemakaian timba selama 12 bulan sebesar Rp. 41.667,-. 
Tabel 6. Rata-rata Biaya Tetap per Hektar per Musim Tanamn pada Usahatani Bawang Merah di Kecamatan Sukomoro Kabupaten Nganjuk, 2014

\begin{tabular}{|r|l|r|r|r|r|}
\hline NO & URAIAN & JUMLAH & $\begin{array}{c}\text { HARGA } \\
\text { BELI } \\
\text { (Rp) }\end{array}$ & $\begin{array}{c}\text { UMUR } \\
\text { EKONOMIS } \\
\text { (bulan) }\end{array}$ & \multicolumn{2}{|c|}{$\begin{array}{c}\text { PENYUSUTAN } \\
\text { (RP) }\end{array}$} \\
\hline 1 & Sewa Lahan & & & & 500.000 \\
\hline 2 & Cangkul & 4 & 100.000 & 24 & 66.667 \\
\hline 3 & Sprayer & 2 & 400.000 & 60 & 53.333 \\
\hline 4 & Parang & 5 & 25.000 & 24 & 20.833 \\
\hline 5 & Timba & 5 & 25.000 & 12 & 41.667 \\
\hline & Jumlah & & & & 682.500 \\
\hline
\end{tabular}

Sumber : data primer diolah, 2014

b. Biaya Sarana Produksi Usahatani

\section{Bawang Merah}

Sarana produksi untuk melakukan usahatani bawang merah terdiri bibit, pupuk urea, ZA, NPK, SP 36, pupuk kandang dan insektisida dan fungisida. Jumlah penggunaan sarana produksi usahatani bawang merah dijelaskan pada Tabel 7. Rata-rata jumlah bibit bawang merah per hektar adalah $893 \mathrm{~kg}$ dengan nilai $\mathrm{Rp}$ 11.967.500,-. $\quad$ Sedangkan rata-rata jumlah pupuk urea sebesar 203 $\mathrm{kg} /$ hektar dengan nilai $\mathrm{Rp} 406.667,-$, rata-rata pupuk ZA sebesar 365 kg/hektar dengan nilai Rp. 584.000,- dan rata-rata pupuk NPK sebesar 750 $\mathrm{kg} /$ hektar dan SP 36 sebesar 201 $\mathrm{kg} /$ hektar. Untuk insektisida rata digunakan dengan jumlah 21 liter/hektar dengan nilai Rp. 1.066.667,- dan fungisida sebesar 23 liter dengan nilai Rp 1.141.667,--

Tabel 7. Rata-rata Biaya Sarana Produksi per Hektar Per Musim Tanam Usahatani Bawang Merah Di Kecamatan Sukomoro Kabupaten Nganjuk, 2014 Tahun

\begin{tabular}{|c|l|r|r|r|}
\hline NO & \multicolumn{1}{|c|}{ URAIAN } & \multicolumn{1}{|c|}{ JUMLAH } & \multicolumn{1}{c|}{ RP/UNIT } & \multicolumn{1}{c|}{ TOTAL (Rp) } \\
\hline 1 & Bibit $(\mathrm{kg})$ & 893 & 13.400 & 11.967 .500 \\
\hline 2 & Pupuk : & & & \\
\hline & Urea $(\mathrm{kg})$ & 203 & 2.000 & 406.667 \\
\hline & ZA $(\mathrm{kg})$ & 365 & 1.400 & 584.000 \\
\hline & NPK $(\mathrm{kg})$ & 750 & 3.000 & 2.250 .000 \\
\hline & SP36 (kg) & 201 & 2.200 & 442.567 \\
\hline & Pupuk kandang (kg) & 4.000 & & 4.000 .000 \\
\hline 3 & Insektisida (liter) & 21 & & 1.066 .667 \\
\hline 4 & Fungisida (liter) & 23 & & 1.141 .667 \\
\hline & JUMLAH & & & 21.859 .067 \\
\hline
\end{tabular}

Sumber : data primer diolah, 2014 


\section{c. Biaya Tenaga Kerja}

Tenaga kerja dalam usahatani bawang merah digunakan mulai dari saat pengolahan lahan, tanam, penyiangan, pemeliharaan dan saat panen. Alokasi penggunaan tenaga kerja disajikan pada Tabel 8. Jumlah total penggunaan tenaga kerja pada usahatani bawang merah adalah 210 hari orang kerja, yang terdiri dari 50 HOK dengan nilai Rp 2.500.000,-pengolahan lahan, $40 \mathrm{HOK}$ tanam dengan nilai $\mathrm{Rp}$ 500.000,-, penyianagan dan penyiraman $10 \mathrm{OHK}$ dengan nilai Rp 500.000 penyiraman, pengendalian hama penyakit dan pemupukan masing-masing 15 HOK dengan nilai $\mathrm{Rp} 600.000$,- dan panen 30 HOK dengan nilai $\mathrm{Rp}$ 1.200.000,-. Upah rata-rata adalah Rp 44.285,-/HOK. Total biaya tenaga kerja sebesar Rp 7.100.000,- /hektar.

Tabel 8. Rata-rata Biaya Tenaga Kerja per Hektar per Musim Tanamn Usahatani Bawang Merah di Kecamatan Sukomoro Kabupaten Nganjuk, 2014

\begin{tabular}{|c|l|r|r|r|}
\hline NO & \multicolumn{1}{|c|}{ URAIAN } & \multicolumn{1}{|c|}{$\begin{array}{l}\text { JUMLAH } \\
\text { (HOK) }\end{array}$} & \multicolumn{1}{c|}{ RP/HOK } & \multicolumn{1}{c|}{$(\mathrm{Rp})$} \\
\hline 1 & Pengolahan lahan & 50 & 50.000 & 2.500 .000 \\
\hline 2 & Tanam & 30 & 40.000 & 1.200 .000 \\
\hline 3 & Penyiangan & 10 & 50.000 & 500.000 \\
\hline 4 & Penyiraman & 10 & 50.000 & 500.000 \\
\hline 5 & Pengendalian hama penyakit & 15 & 40.000 & 600.000 \\
\hline 6 & Pemupukan & 10 & 40.000 & 600.000 \\
\hline 7 & Panen & 30 & 40.000 & 1.200 .000 \\
\hline & Jumlah & 210 & & 7.100 .000 \\
\hline
\end{tabular}

Sumber : data primer diolah, 2014

\section{d. Total Biaya Produksi Usahatani Bawang Merah}

Total biaya produksi usahatani bawang merah di Kecamatan Sukomoro adalah sebesar Rp 29.641.567,- dengan rincian biaya tetap sebesar Rp. 682.500,, biaya variabel sebesar Rp 28.959.067,yang terdiri dari sewa lahan Rp. $500.000,-, \quad$ biaya penyusutan $\mathrm{Rp}$.
182.500,-, bibit Rp. 11.967.500,-, Pupuk Urea Rp. 406.667,-, ZA Rp. 584.000,-, NPK Rp. 2.250.000,-, SP36 Rp. 442.567,-, Rp. Pupuk Kandang Rp. 4.000.000,-, Insektisida Rp. 1.066.667,-, Fungisida Rp.1.141.667,- dan tenaga kerja Rp.7.100.000,-. 
Tabel 9. Rata-rata Biaya Produksi Total Usahatani Bawang Merah

\begin{tabular}{|c|l|r|}
\hline NO & \multicolumn{1}{|c|}{ URAIAN } & \multicolumn{1}{|c|}{ Biaya (Rp/Ha) } \\
\hline 1 & Biaya Tetap & 500.000 \\
\hline & Sewa lahan & 182.500 \\
\hline & Biaya penyusutan & 11.967 .500 \\
\hline & Biaya Variabel & 406.667 \\
\hline & Bibit & 584.000 \\
\hline & Urea & 2.250 .000 \\
\hline & ZA & 442.567 \\
\hline & SPK & 4.000 .000 \\
\hline & Pupuk kandang & 1.066 .667 \\
\hline & Insektisida & 1.141 .667 \\
\hline & Fungisida & 7.100 .000 \\
\hline 3 & Tenaga kerja & 29.641 .567 \\
\hline & JUMLAH &
\end{tabular}

Sumber : data primer diolah, 2014

\section{a. Produksi dan Penerimaan}

\section{Usahatani Bawang Merah}

Tabel 10. Produksi, Penerimaan, dan Efisiensi per Hektar Usahatani Bawang Merah di Kecamatan Sukomoro Kab. Nganjuk Tahun 2014

\begin{tabular}{|c|l|r|}
\hline NO & \multicolumn{1}{|c|}{ URAIAN } & \multicolumn{1}{|c|}{ JUMLAH } \\
\hline 1 & Produksi $(\mathrm{kg})$ & 9.035 \\
\hline 2 & Harga jual $(\mathrm{Rp} / \mathrm{Kg})$ & 4.983 \\
\hline 3 & Penerimaan $(\mathrm{Rp} / \mathrm{Ha})$ & 45.024 .417 \\
\hline 4 & Biaya produksi $(\mathrm{Rp} / \mathrm{Ha})$ & 29.641 .567 \\
\hline 5 & Keuntungan $(\mathrm{Rp} / \mathrm{Ha})$ & 15.382 .850 \\
\hline 6 & R/C Ratio & 1,52 \\
\hline
\end{tabular}

Sumber: data primer diolah, 2014

Rincian produksi dan penerimaan usahatani bawang merah antara lain produksi $9.035 \mathrm{~kg}$, harga jual $\mathrm{Rp}$. 4.983,-, penerimaan Rp. 45.024.417,-, biaya produksi $29.641 .567,-$ keuntungan Rp. 15.382.850,- dan R/C Ratio sebesar 1,52 .

2). Analisis Efisiensi Usahatani Bawang Merah Yang Menerapkan Pasca Panen

Penerapan tehnologi pasca panen menyebabkan meningkatkan biaya produksi khususnya biaya tenaga kerja untuk kegiatan pengeringan, pembersihan, pengikatan; grading, pengemasan, penyimpanan, bahan kimia dan transportasi. 
Tabel 11. Rata-rata Biaya Produksi Total Usahatani

\begin{tabular}{|c|c|c|}
\hline NO & URAIAN & Biaya (Rp/Ha) \\
\hline \multirow[t]{3}{*}{1} & Biaya Tetap & \\
\hline & Sewa lahan & 500.000 \\
\hline & Biaya penyusutan & 182.500 \\
\hline \multirow[t]{9}{*}{2} & Biaya Variabel & \\
\hline & Bibit & 11.967 .500 \\
\hline & Urea & 406.667 \\
\hline & $\mathrm{ZA}$ & 584.000 \\
\hline & NPK & 2.250 .000 \\
\hline & SP36 & 442.567 \\
\hline & Pupuk kandang & 4.000 .000 \\
\hline & Insektisida & 1.066 .667 \\
\hline & Fungisida & 1.141 .667 \\
\hline \multirow[t]{2}{*}{3} & 1. Tenaga kerja usahatani & 7.100 .000 \\
\hline & 2. Tenaga kerja pasca panen & 2.914 .020 \\
\hline 4 & JUMLAH BIAYA PRODUKSI & 32.555.587 \\
\hline 5 & PRODUKSI & $\mathbf{9 . 0 3 5}$ \\
\hline 6 & HARGA JUAL (Rp/kg) & 6000 \\
\hline 7 & PENERIMAAN (Rp/ha) & 67.762 .500 \\
\hline 8 & KEUNTUNGAN (Rp/ha) & 35.206 .913 \\
\hline 9 & $\mathrm{R} / \mathrm{C}$ ratio & 2,08 \\
\hline
\end{tabular}

Sumber : diolah dari data primer, 2014

Berdasarkan hasil perhitungan diketahui bahwa penerapan praktek pasca panen menghasilkan nilai $\mathrm{R} / \mathrm{C}$ ratio sebesar 2,08, artinya setiap $\mathrm{Rp} 1,-$ biaya produksi yang dikeluarkan akan memberikan penerimaan sebesar $\mathrm{Rp}$ 2,08,-. Nilai ini lebih besar apabila dibandingkan dengan nilai $\mathrm{R} / \mathrm{C}$ ratio 1,52, artinya setiap $\mathrm{Rp} 1,-$ biaya produksi yang dikeluarkan akan menghasilkan penerimaan sebesar $\mathrm{Rp}$ 1,52,-. Dengan demikian dapat disimpulkan bahwa penerapan praktik pasca panen akan meningkatkan efisiensi dan keuntungan usahatani bawang merah sebesar $36,84 \%$.

tidak menerapkan pasca panen yaitu 
Model Organisasi Penanganan Pasca Panen Dan Pengolahan Hasil Bawang Merah dengan Menggunakan Pendekatan Kelompok (Gapoktan).

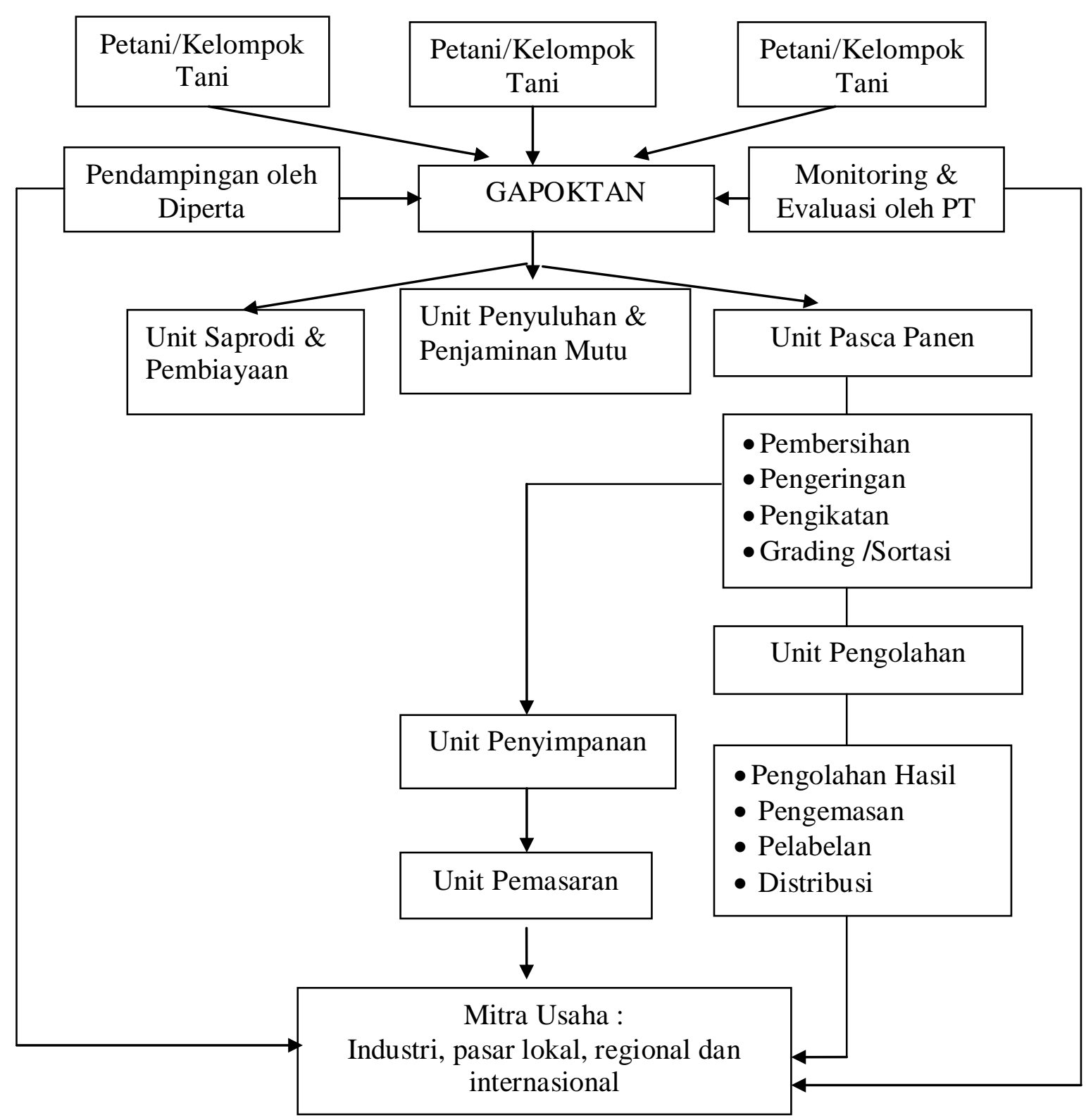

Gambar 1 . Model Pengambangan Kelembagaan Pasca Panen dan Pengolahan Hasil Bawang Merah dengan Pendekatan GAPOKTAN pada Usahatani Bawang Merah DI kecamatan Sukomoro Kabupaten Nganjuk

\section{KESIMPULAN DAN SARAN}

\section{Kesimpulan}

Hasil penelitian menunjukkan

bahwa hanya $20 \%$ petani bawang merah

di Kecamatan Sukomoro Kabupaten
Nganjuk menerapkan praktik pasca panen, yakni melakukan pembersihan, pengikatan, pengeringan, grading, pengemasan, penyimpanan, pemberian bahan kimia (kalsium) dan transportasi. 
Dengan penerapanan praktik pasca panen ini dapat meningkatkan efisiensi usahatani bawang merah dari 1.52 menjadi 2,08; artinya keuntungan usahatani meningkat sebesar $24,34 \%$. Selama ini petani bawang merah belum mengorganisir kegiatan pasca panen dalam kelompok tani tetapi masih berjalan sendiri-sendiri. Oleh karena itu telah disusun Model Kelembagaan Pasca Panen, Pengolahan Hasil dan Kemitraan Usaha Berbasis Pendekatan Kelompok (Gapoktan) agar dapat mengatasi permasalahan tehnis, ekonomi dan sosial petani dalam mengembangkan praktik pasca panen dan pengolahan hasil.

\section{Saran}

Sebagai tindak lanjut kegiatan penelitian di tahun yang akan datang adalah melakukan sosialisasi dan uji coba Model Kelembagaan Pasca Panen, Pengolahan Hasil dan Kemitraan Usaha yang Berbasis Gapoktan serta mengukur respon petani terhadap model. Melalui penerapana model diharapkan agar pendapatan dan keuntungan usahatani semakin meningkat dan kesejahteraan petani meningkat di sisi lain ketersediaan bawang merah di pasaran tercukupi.

\section{DAFTAR PUSTAKA}

Anonymous, 2013. Diskusi bawang merah, antara cerita dan derita. Agritusi Farm 19 Maret 2013. http://agritusi.com/archives/458 diakses 20 Maret 2013.

Ari Jumadi K dkk (2010). Distribusi Bawang Merah Dan Bawang Putih Di Kota Banjarmasin. Fakultas Pertanian Universitas Islam Kalimantan Muhammad Arsyad Al Banjary. ISSN 20853548.

Asosiasi Bawang Merah Indonesia, 2013. Cara Budidaya Bawang Merah.

http://asosiasibawangmerah.blog spot.com/2013/01/carabudidaya-bawang-merah.html diakses tanggal 16 April 2013.

Baswarsiati, 2009. Budidaya Bawang Merah dan Penanganan Permasalahannya. BPPT Jawa Timur.

http://baswarsiati.wordpress.co $\mathrm{m} / 2009 / 04 / 24 /$ budidaya-

bawang-merah-dan-penangananpermasalahannya/ diakses tanggal 7 Maret 2013.

Direktorat Jenderal Pengolahan Dan Pemasaran Hasil Pertanian, 2006. Road Map Pasca Panen, Pengolahan Dan Pemasaran Hasil Bawang. Jakarta.

Fitri Prima Nanda, Ira mega dan Iqlima Idayah, 2011. Tinjauan Pasar Bawang Merah. Kementrian Perdagangan. Edisi Bawang Merah. Desember 2011.

Gibson, James L; John M. Ivancevich; dan James $\mathrm{H}$. Donnelly, Jr., 1997,

Organizations; Behavior, Structure and Processes., Ninth Edition.

J. Dwi Narwoko, 2006. Sosiologi. Teks Pengantar dan Terapan. Kencana Perdana Media Group. Jakarta. 
Kementerian Pertanian. 2009. Rancangan Rencana Strategis Kementerian Pertanian Tahun 2010-

2014. http://www.docstoc.com/do cs/38181606/RANCANGANRENCANA-STRATEGISKEMENTERIAN-PERTANIANTAHUN-2010-2014

http://www.docstoc.com/docs/38181606 /RANCANGAN-RENCANASTRATEGIS-KEMENTERIANPERTANIAN-TAHUN-20102014. Diakses tanggal 20 April 2013

Litbang Pertanian, 2006. Prospek dan Arah Pengembangan Agribisnis Bawang Merah. http://www.litbang.deptan.go.id/s pecial/publikasi/doc_hortikultural bawangmerah/bawang-bagianb.pdf diakses tanggal 12 April 2013.
Soerjono Soekanto, 2002. Sosiologi Suatu Pengantar. UI Press. Jakarta.

Sugiyono, 2008. Memahami Penelitian Kualitatif. Alfabet. Bandung

Witono Adiyoga, Mieke Ameriana dan Achmad Hidayat, 1999. Segmentasi Dan Integrasi Pasar: Studi Kasus Dalam Sistempemasaran Bawang Merah. Jurnal Hortikultura, Tahun 1999, Volume 9, Nomor (2): 153-163.

Yulianti dan Nilam Sari, 2007. Kelayakan Usaha Agroindustri Bawang Goreng Palu Di Kabupaten Donggala. J. Agroland 15 (3) : 216 - 222, September 2008. ISSN : $0854-$ 641X 